Turkish Psychological Counseling and Guidance Journal

Türk Psikolojik Danışma ve Rehberlik Dergisi
Uzun \& Deniz (2021)

Vol: 11 Number: 62 Page: 419-432 ISSN: 1302-1370

\title{
Investigation of The Effectiveness of the Mindfulness-Based Group Psychological Counseling Program in Couples
}

\author{
Ciftlerde Bilinçli Farkındalık Temelli Grupla Psikolojike Danısma Programmm Etkililiğinin Incelenmesi
}

\section{Gülgün Uzun ㅁ, Mehmet Engin Deniz 주}

Authors Information
Gülgün Uzun
Dr, Ministry of Education,
İstanbul, Turkey,
gulgun gcn@,hotmail.com
Mehmet Engin Deniz

Professor, Yildız Teknik

University, İstanbul, Turkey

edeniz@,yildiz.edu.tr

\begin{abstract}
The study aims at the effects of mindfulness-based group counseling programs on interpersonal mindfulness levels. This is an experimental study with experimental and control groups based on the pretest, posttest, and follow-up models. The research consists of couples who are married for at least 1 year and graduated from secondary education in İstanbul. The data of the study were obtained with the mindfulness in marriage scale. A 10 -week mindfulness-based psychological counseling program was applied to the experimental group by the researcher. Any training was not given to the control group. Follow-up measurement for the experimental group was performed two months after the posttest. As a result of the research findings, a mindfulness-based psychological group counseling program increased the Interpersonal mindfulness scores of the couples. It is seen that there is a significant difference between the mindfulness pre-test-post-test and pre-test-follow-up test scores of the married couples in the experimental group. However, there is no statistically significant difference between the mindfulness pre-test and post-test scores of married couples in the control group.
\end{abstract}

\begin{tabular}{l}
\hline Article Information \\
\hline Keywords \\
Interpersonal Mindfulness in \\
Marriage \\
Couples \\
Marriage \\
Group Counseling Program \\
Anahtar Kelimeler \\
Evlilikte Bilinçli Farkındalık \\
Çiftler \\
Evlilik \\
Grupla Psikolojik Danısma \\
Programı \\
Article History
\end{tabular}

\section{ÖZET}

$\mathrm{Bu}$ araştırmada, bilinçli farkındalık temelli grupla psikolojik danışma programını evli çiftlerin "evlilikte kişilerarası bilinçli farkındalık" düzeylerine etkisi incelenmesi amaçlanmaktadır. Araştırma, deney ve kontrol gruplu; ön test, son test, izleme testi modeline dayalı deneysel bir çalışmadır. Araştırma, İstanbul ilinde yaşayan en az 1 yıllık evli ve en az ortaöğretim mezunu çiftlerden oluşmaktadır. Araştırmanın verileri "Evlilikte Bilinçli Farkındalık ölçeği” ile elde edilmiştir. Deney grubuna araştırmacı tarafindan 10 haftalık bilinçli farkındalık temelli grupla psikolojik danışma programı uygulanmıştır. Kontrol grubuna herhangi bir program uygulanmamışır İzleme ölçümleri, son test uygulamasından iki ay sonra yapılmıştır. Elde edilen araştırma bulgularının sonucunda, uygulanan grupla psikolojik danışma programı, uygulamaya katılan çiftlerin evlilikte bilinçli farkındalık puanlarını artırmıştır. Deney grubunda yer alan evli çiftlerin bilinçli farkındalık ön test-son test ve ön test-izleme testi puanları arasindan anlamlı farklılık olduğu görülmektedir. Ancak kontrol grubunda yer alan evli çiftlerin bilinçli farkındalık ön test ve son test puanları arasında istatistiksel olarak anlamlı bir farklılık bulunmamaktadır.

ed: $08 / 06 / 2021$

Revision: 15/08/2021

Accepted: $17 / 08 / 2021$

Cite this article as: Uzun, G., \& Deniz, M.E. (2021). Investigation of the effectiveness of the mindfulness-based group psychological counseling program in couples. Turkish Psychological Counseling and Guidance Journal, 11(62), 419-432. https://doi.org/10.17066/tpdrd.1001726 


\section{INTRODUCTION}

Marriage is an institution that enables two different individuals to fulfill various goals such as making their lives meaningful, having a child, obtaining a respectable status, coping with life's difficulties, and taking on the roles and responsibilities of this world together (Özuğurlu, 2013). The concept of marriage has been important for human beings for centuries, and countless studies have been carried out on this subject. Some of these studies are associated with the concept of conscious mindfulness and have attracted the attention of researchers in recent years.

Mindfulness is defined as "focusing on the moment the individual lives, paying attention to the events in the current period" (Baer, 2003; Brown \& Ryan, 2003; Kabat-Zinn, 2003; Wachs \& Cordova, 2007). When the studies on mindfulness and marriage are examined, it is seen that it has a positive effect on couples' interaction patterns (Kabat-Zinn, 2005); and their marital satisfaction is high (Barnes et al., 2007; Carson et al., 2004; Deniz, 2017; Deniz, Erus \& Batum, 2020; Gambrel \& Keeling, 2010; Gambrel \& Piercy, 2015a, 2015b; Jones et al., 2011; Lenger, Gordon \& Nguyen, 2017; Parlar \& Akgün, 2018; Seller, 2018; Wachs \& Cordova, 2007; Williams \& Cano, 2014; Erus, 2019; Batum, 2020).

The concept of mindfulness has emerged as two separate research concepts as intrapersonal mindfulness and interpersonal mindfulness (Erus, 2019). Intrapersonal mindfulness is the concentration of an individual on his / her feelings, thoughts, and experiences (Bishop et al., 2004; Duncan, 2007). Based on this definition, we can say that the concept of intrapersonal mindfulness is like the traditional conscious mindfulness concept (Duncan, Coatsworth \& Greenberg, 2009). Interpersonal mindfulness is stated as that the individual communicates and interacts with mindfulness, being aware of his / her thoughts, feelings, and body sensations at the time of communication, and being able to pay attention to what the person communicates with, his behavior, mood, tone of voice and body language (Pratscher et al., 2019). Erus and Deniz (2018) emphasize that the concept of interpersonal mindfulness emerges when an individual is in a relationship and communicating with another individual.

When studies on interpersonal mindfulness are examined, it has been found that it increases the level of effective communication (Atkinson, 2013; Bögels, Lehtonen \& Restifo, 2010; Burgoon, Berger \& Waldron, 2000; Coatsworth et al., 2010; Cohen, \& Miller, 2009; Erus, 2019; Pratscher et al., 2019), and it contributes the quality of friendship (Pratscher et al., 2018), teacher-student relationship (Elreda et al., 2019; Frank, Jennings \& Greenberg, 2016), parent-child relationship (Bögels, Lehtonen \& Restifo, 2010; Gouveia et al., 2016; Lippold et al., 2015; McCaffrey, 2015; McCaffrey, Reitman \& Black 2017; Parent et al., 2016), self-understanding and personality traits (Batum, 2020), marital life satisfaction (Sipahi, 2020).

Interpersonal mindfulness and in marriage means "listening carefully to the spouse during the interaction and communication process, being aware of the feelings of himself and his spouse, and accepting his and his wife's feelings without judgment" (Erus, 2019).

When studies on interpersonal mindfulness in the marriage relationship are examined, it was found that there is a significant positive relationship between emotional intelligence, marital adjustment, subjective well-being (Erus, 2019), and marital satisfaction (Deniz, Erus, Batum, 2020), and there is a significant negative relationship with emotional regulation difficulties (Deniz, Batum, Erus, 2019). In line with all these results, it can be said that the concept of interpersonal mindfulness in marriage plays an effective role in a healthy marital relationship. 
Based on the above-mentioned theoretical background, it is seen that the studies conducted are in a relational pattern. In this study, the effectiveness of the " Mindfulness-Based Group Counseling Program in Marriage" designed to increase the interpersonal mindfulness level of married couples was tested. This study is important in that it is the first experimental study for couples in Turkey, based on the interpersonal Mindfulness in Marriage Relationship approach. It is thought that the mindfulness-based group psychological counseling program for couples will make an important contribution to the literature in which it will play an effective role in increasing the level of interpersonal mindfulness in married couples. The problem of this research is to seek an answer to the question of "Does the mindfulnessbased group counseling program for couples affect the interpersonal mindfulness levels in married couples?".

\section{Purpose of the Research}

This study aims to examine the effects of the mindfulness-based group psychological counseling program on the interpersonal mindfulness levels in married couples. In the research, the following hypotheses were tested in line with this general purpose.

1. There is no significant difference between the married couples in the experimental group and the married couples in the control group in terms of pre-test scores of interpersonal mindfulness in marriage; There is a difference in favor of the experimental group in the post-test.

2. While there is a significant difference between the pre-test-post-test and pre-test-follow-up test scores of the married couples in the experimental group, there is no significant difference when compared in terms of the post-test-follow-up test. When the interpersonal mindfulness in marriage scores of married couples in the control group was compared in terms of pre-test and post-test, there was no statistically significant difference between these measurements.

\section{METHOD}

\section{Research Model}

In this study, an experimental model, which can be shown as a pre-test, post-test, follow-up test, with measurements and $2 \times 3$ control groups frequently used in social sciences, was used. In this model, the first factor is to show the experimental treatment groups (experimental-control), the second factor is to show the repeated measures (pre-test-post-test-follow-up test) of the dependent variable (Büyüköztürk et al., 2009). The independent variable of the research is a group counseling program applied to the experimental group. The dependent variable is the interpersonal mindfulness level of couples in marriage. The pattern of the research is presented in Table 1.

\begin{tabular}{llll}
\hline \multicolumn{3}{l}{ Table 1. Research design representation } & \\
\hline Group & 1st. MeasurementProcedure & $\begin{array}{l}\text { 2nd. } \\
\text { Measurement }\end{array}$ & $\begin{array}{l}\text { 3rd. } \\
\text { Measurement }\end{array}$ \\
\hline Experiment & Pre-Test & $\begin{array}{l}\text { Experimental } \\
\text { Group Counseling Program) }\end{array}$ & (Mindfulness-BasedPost-Test \\
\hline Control & Pre-Test & & Pollow-up-Test \\
\hline
\end{tabular}

\section{Study Group}

The research group consists of married couples living in Istanbul. The criteria for the participants to be included in the study are being volunteers, at least having one year of marriage, and at least being a high 
school graduate. There are two different groups in the research as experimental and control. When the groups' distribution is examined, there are 8 pairs in the experimental group and 8 pairs in the control group. In the selection of the participants, those who scored low on the scales were included in the study, and it was aimed to include members who could achieve the highest possible efficiency from the group by excluding those with high scores from the study. Volunteer individuals whose scores were close to each other were randomly assigned to the experimental and control groups. The research was completed with 32 individuals. There are a total of 32 participants in the experimental and control groups, of which $16(50 \%)$ are women, and $16(50 \%)$ are men. Considering the distribution of the participants by age groups, it is seen that the couples participating in the Mindfulness-Based Group Counseling program are mostly in the 31-40 age group (40.62\%). Considering the education status of the couples, it has been determined that they are mostly graduates of master's degree (42.75) and the least is the graduates of secondary education (9.38). Information on the participants of the study is given in Table 2.

Table 2. Information on participants

\begin{tabular}{lll}
\hline Variable & f & \% \\
\hline Gender & & \\
Female & 16 & 50 \\
Male & 16 & 50 \\
\hline Age & & \\
Between 20-30 & 9 & 28.13 \\
Between 31-40 & 13 & 40.62 \\
Between 41-50 & 10 & 31.25 \\
\hline Educational Status & & \\
Secondary Education & 11 & 34.37 \\
Undergraduate & 3 & 9.38 \\
Post Graduate & 14 & 43.75 \\
Doctorate & 4 & 12.5 \\
\hline
\end{tabular}

\section{Ethical Statement}

Ethical approval was obtained from the Ethics Committee at Yeldız Technical University (Ref: 104129). The consent form was obtained from all participants indicating that they voluntarily participated in this study.

\section{Data Collection Tools}

Mindfulness in Marriage Scale. Mindfulness in Marriage Scale (MMS), which aims to determine the level of interpersonal mindfulness in the marriage relationship, consists of 12 items and is developed by Erus and Deniz (2018). The scores obtained from the scale determine the level of interpersonal c mindfulness of married individuals in their relationships with their spouses. According to the results of principal components analysis, a single factor structure that explains $42.70 \%$ of the variance was determined. Cronbach alpha internal consistency coefficient of the MMS was obtained in a single-factor structure and the final form of the 12-item scale to determine the level of interpersonal consciousness mindfulness in marital relationships. A 5-point Likert-type rating was used to measure the expressed quality of each item in the scale. MMS is scored as "1 = Never", "2 = Rarely", " 3 = Sometimes", "4 = Most of the Time" and " $5=$ Always". There are 2 reverse items on the scale. The highest score that can be obtained from the scale is 60 , and the lowest score is 12 . The high score obtained from the scale is considered to be a high level of interpersonal conscious mindfulness in the relationship and 
communication of the individual with his / her spouse. Item-total correlations were found to be positively significant.

\section{Data Collection}

To determine the participants to be in the experimental and control groups of the study, the scales were applied by the researcher to the volunteer couple participants in Istanbul. Participants with low scores on the scales were included in the study and participants with high scores were excluded from the study. Volunteers whose scores were close to each other were randomly assigned to the experimental and control groups. After the married couples were assigned to the experimental and control groups, "Mindfulness-Based Group Psychological Counseling Program in Married Couples" was applied to the experimental group, and no procedure was applied to the control group. After the procedure was applied to the experimental group, the scales that were applied as a pre-test were re-applied to the experimental and control groups, and it was checked whether there was a significant difference or not. If it is concluded that the study is effective, follow-up measurements were made to show that this result is independent of time and expectations. For this reason, to test whether the effect of " Mindfulness-Based Conscious Group Psychological Counseling Program in Married Couples" is long-lasting and independent of the effect of time, the post-test scales were applied to the experimental group as a follow-up study, two months after the end of the applications.

\section{Content and Process of Mindfulness-Based Group Counseling Program in Married Couples}

The program consists of 10 sessions, each lasting an average of 90 minutes. Married couples participated in the program together. Within the framework of mindfulness principles, the program aims to get rid of the feelings, thoughts, and memories that disturb them in their marriage, to accept them instead of trying to control them, to help them to focus on the present moment and to determine their goals and important life events that will add meaning and direction to their lives and act in this direction, to help spouses, to gain conscious awareness communication skills and empathy skills, to recognize emotions and thoughts and to deal with difficult emotions, to help them to improve themselves in subjects such as forgiving, being grateful, being kind, expressing their gratitude, etc.. It has been prepared to improve oneself in their subjects and develop compassion for themselves and their spouse. The content of the MindfulnessBased Group Psychological Counseling Program in Married Couples, applied to the experimental group in the study is presented below.

Session 1: Getting Started and Introducing the Program, Getting Become acquainted with and Configuring the Program

Session 2: Being Here and Now, Breath and Body Awareness, Warming up of the Group, Mindfulness, Focus on the Moment, Mindfulness Exercises

Session 3: Discovering himself and His Partner - Awareness, Being aware of the characteristics of the couple in the relationship, and accepting them as they are.

Session 4: Exploration of Emotions - Acceptance and Deal with Difficult Emotions, Mindfulness of couples' feelings and thoughts, Developing skills to cope with negative emotions, Increasing positive emotions

Session 5: Mindfulness of Positive and Negative Experiences in the Relationship, Reviewing and accepting the unpleasant and pleasant memories of the couples, being able to talk with spouses about 
negative experiences, Being able to approve, appreciate, use expressions of affection in the relationships of the group members with their spouses

Session 6: Focusing on the Moment in the Relationship - Communicating by Living the Here and Now, Focusing on the time spent with the partner, Gaining empathy skills

Session 7: Quality Time Spending -Planning the Time, Providing Couples with Conscious Mindfulness Speaking Skills, Quality Time Spending of Couples

Session 8: Forgiveness and Gratitude in the Relationship, The ability of couples to forgive themselves and their spouses, To be aware of the situations that couples are grateful for in the face of difficult situations, and the ability of the couples to send good wishes to each other

Session 9: Developing Self-Compassion in Relationship, Gaining the ability of group members to show compassion to themselves and their spouses in their relationships

Session 10: Ending, Farewell Time, Evaluation of the group process-Love Bombardment

\section{Data Analysis}

Due to the small number of participants and the lack of normal distribution, the Mann Whitney $U$ test and the Wilcoxon Signed Ranks Test was used in this study for unrelated measurements (Büyüköztürk, Çokluk \& Köklü, 2013).

By calculating the scores of each married couple in the experimental and control groups, it is planned to examine whether there is a significant difference between the experimental and control groups in terms of their scores with the Mann-Whitney $U$ test. In the research analysis, to examine the effects of the mindfulness-based group psychological counseling program in married couples on the interpersonal mindfulness levels of married couples in the sub-hypotheses, the Friedman Test was used to examine whether there was a difference between the three measurements, namely pre-test, post-test, and followup test. If there was a difference between the measurements, Wilcoxon Signed Ranks Test was used to determine which measurements that the differences exist. It was discussed that there is a difference between the measurements. However, whether there is a difference between the two measurements, as the pre-test and the post-test in the control group, was examined with the Wilcoxon Signed Ranks Test (Büyüköztürk, 2012).

\section{RESULTS}

In this part of the study, findings for the test of the effectiveness of mindfulness-based group counseling programs in married couples are included. In this context, firstly, the pre-test and post-test data obtained from the experimental and control groups were examined by comparing between groups. Then, the pretest, post-test, and follow-up test measurements of the experimental group and the pre-test and post-test measurements of the control group were compared within themselves. Thus, the effectiveness of the mindfulness-based group counseling program was examined in terms of interpersonal mindfulness scores in marriage. 
Findings regarding the comparison of interpersonal mindfulness scores of married couples in the experimental and control groups in terms of pre-test and post-test

The mindfulness pre-test and post-test data obtained from the experimental and control groups were analyzed comparatively. Mann-Whitney $\mathrm{U}$ test was used for this analysis. The findings obtained as a result of the examination are presented in Table 3.

Table 3. Comparison of interpersonal mindfulness scores of married couples in the experimental group and the control group in terms of pre-test and post-test

\begin{tabular}{llllllll}
\hline \multirow{2}{*}{ Score } & Groups & $\mathbf{N}$ & $\bar{x}_{\text {sira }}$ & $\sum_{\text {sira }}$ & $U$ & $z$ & $p$ \\
\hline \multirow{2}{*}{ Pre-Test } & Experimental & 16 & 14.91 & 238.50 & \multirow{2}{*}{102.500} & -.970 & .33 \\
& Control & 16 & 18.09 & 289.50 & & & \\
& Experimental & 16 & 24.31 & 389.00 & & & \\
\multirow{2}{*}{ Post-Test } & Control & 16 & 8.69 & 139.00 & 3.000 & -4.723 & .00 \\
\hline p $<0,05$ & & & &
\end{tabular}

As seen in Table 3, while there is no statistically significant difference between the pre-test $(\mathrm{U}=102.500$, $\mathrm{Z}=-.970, \mathrm{p}>.05)$ scores of the married couples in the experimental group and the control group, there is a statistically significant difference between the post-test scores of conscious mindfulness in marriage, in favor of the experimental group $(\mathrm{U}=3.000, \mathrm{Z}=-4.723, \mathrm{p}<.01)$. In conclusion, before the application, the interpersonal mindfulness scores of married couples in the experimental and control groups did not differ. After the application, while the interpersonal mindfulness scores of married couples in the experimental group increased, although a program was not applied to the married couples in the control group, the mindfulness scores in marriage decreased.

Findings regarding the comparison of interpersonal mindfulness scores of married couples in the experimental and control groups in terms of pre-test-post-test, pre-test-follow-up test, and post-test-follow-up test

In this section, the findings obtained as a result of the comparison of the pre-test, post-test, and followup test scores of interpersonal mindfulness in marriage obtained from the experimental and control groups within the group are included. In this context, whether there is a difference between the three measurements, pre-test, post-test, and follow-up test performed in the experimental group, was examined using the Friedman Test, and if there was a difference between the measurements, the Wilcoxon Signed Ranks Test was used to evaluate which measurements were different. However, the Wilcoxon SignedRanks Test was examined whether there was a difference between the two measurements -pre-test and post-test in the control group. In Table 4, the results of the Friedman Test of pre-test, post-test, and follow-up test measurements for the comparison of interpersonal mindfulness in the marriage of the experimental group are shown, and in Table 5, the Wilcoxon Signed Ranks Test for the comparison of the pre-test and post-test measurements of interpersonal mindfulness in marriage in the control group are shown.

Table 4. Analysis results of married couples in the experimental group regarding the pre-test, post-test, and follow-up test scores of interpersonal mindfulness in marriage

\begin{tabular}{|c|c|c|c|c|c|c|}
\hline & Scores & $\mathbf{n}$ & $\bar{x}_{\text {sira }}$ & $x^{2}$ & Sd & $p$ \\
\hline \multirow{2}{*}{$\begin{array}{l}\text { Interpersonal } \\
\text { Mindfulness }\end{array}$} & Pre-Test & 16 & 1.00 & \multirow[b]{2}{*}{27.263} & \multirow[b]{2}{*}{2} & \multirow[b]{2}{*}{.00} \\
\hline & $\begin{array}{l}\text { Post-Test } \\
\text { Follow-up-Test }\end{array}$ & $\begin{array}{l}16 \\
16\end{array}$ & $\begin{array}{c}2.59 \\
2.41\end{array}$ & & & \\
\hline
\end{tabular}


As seen in Table 4, there is a statistically significant difference between the pre-test, post-test, and followup test scores of the experimental group for interpersonal mindfulness in marriage $\left(x^{2}=27.263 ; p<.05\right)$. The Wilcoxon Signed Ranks Test results were applied to determine whether there is a difference between which measurements are presented in Table 5.

Table 5. Analysis results of the comparison of pre-test-post-test-follow-up test measurements of married couples' interpersonal mindfulness scores in the experimental group

\begin{tabular}{|c|c|c|c|c|c|c|}
\hline Compared Scores & Groups & $\mathbf{n}$ & $\bar{x}_{\text {sira }}$ & $\sum$ & $\mathrm{Z}$ & $p$ \\
\hline \multirow[t]{3}{*}{ Pre-Test-Post-Test } & Decreased & 0 & .00 & .00 & \multirow[t]{3}{*}{-3.522} & \multirow[t]{3}{*}{00} \\
\hline & Increased & 16 & 8.50 & 136.00 & & \\
\hline & Equal & 0 & & & & \\
\hline \multirow{4}{*}{ Pre-Test-Follow-Up- } & Decreased & 0 & .00 & .00 & \multirow{4}{*}{-3.521} & \multirow{4}{*}{.00} \\
\hline & est & & & & & \\
\hline & Increased & 16 & \multirow[t]{2}{*}{8.50} & 136.00 & & \\
\hline & Equal & 0 & & & & \\
\hline \multirow{3}{*}{$\begin{array}{l}\text { Post-Test-Follow-Up } \\
\text { Test }\end{array}$} & Decreased & 6 & 4.67 & 28.00 & \multirow{3}{*}{-.666} & \multirow{3}{*}{.50} \\
\hline & & & & & & \\
\hline & Increased & $\begin{array}{l}3 \\
7\end{array}$ & 5.67 & 17.00 & & \\
\hline
\end{tabular}

$\mathrm{p}<0,05$

As seen in Table 5, it is seen that there is a significant difference between the pre-test-post-test $(\mathrm{z}=$ 3.522, $\mathrm{p}<.05)$ and the pre-test-follow-up test $(\mathrm{z}=-3.521, \mathrm{p}<.05)$ scores interpersonal mindfulness of married couples in the experimental group. Again, in Table 4, it is seen that there is no significant difference between the post-test-follow-up test $(z=-.666 \mathrm{p}>.05)$ scores. Consequently, the interpersonaş mindfulness post-test and follow-up test scores of married couples in the experimental group increased significantly compared to the pre-test scores. In Table 6, there is the Wilcoxon Signed Ranks Test for comparing the pre-test and post-test measurements of interpersonal mindfulness of married couples in the control group.

Table 6. Analysis results of married couples in the control group regarding the pre-test and post-test scores of interpersonal mindfulness in marriage

\begin{tabular}{lllllll}
\hline Compared Scores & Groups & $\mathbf{n}$ & $\bar{x}_{\text {sira }}$ & $\sum$ & $\mathbf{Z}$ & p \\
\hline Pre-Test-Post-Test & Decreased & 2 & 2.25 & 4.50 & & \\
& Increased & 1 & 1.50 & 1.50 & .816 & .414 \\
& Equal & 13 & & & & \\
\hline
\end{tabular}

As seen in Table 6, there is no statistically significant difference between the interpersonal mindfulness pre-test and post-test scores of married couples in the control group $(\mathrm{z}=.816, \mathrm{p}>0.05)$. As a result, there is no difference between the pre-test and post-test scores of interpersonal mindfulness of married couples in the control group. 


\section{DISCUSSION, CONCLUSION \& SUGGESTIONS}

This study aims to examine the effect of mindfulness-based group counseling programs on the interpersonal mindfulness level of married couples As a result of the research, it is a result that supports the purpose of the study that there is a significant increase in interpersonal mindfulness in marriage scores of couples who participated in a group psychological counseling program, which was prepared to increase interpersonal mindfulness in couples, compared to those who did not participate in this program.

The results obtained from the statistical analysis applied to the data obtained from the measurements in the different period time of the study has shown that the following hypothesizes were verified; the first hypothesis of the study was "There is no significant difference in interpersonal mindfulness pre-test scores of married couples in the experimental group and married couples in the control group, and there is a difference in favor of the experimental group in the post-test." The second hypothesis of the study was "While there is a significant difference between the pre-test-post-test and pre-test-follow-up test scores of the married couples in the experimental group, there is no significant difference when compared in terms of the post-test-follow-up test and when the interpersonal mindfulness scores of married couples in the control group are compared in terms of pre-test and post-test, there is no statistically significant difference between these measurements."

As a result of the research, it was found that the interpersonal mindfulness levels of the couples who participated in the "mindfulness-based group psychological counseling program for couples" increased significantly in the post-test measurements made at the end of the experimental application compared to the pre-test measurements. In other words, it has been found that the "mindfulness-based group psychological counseling program" is effective in increasing the interaction, communication, harmony between spouses, and interpersonal mindfulness levels in marriage. When the relevant studies are examined, it is possible to say that this study is the first in this respect that there is no experimental study conducted with the concept of "interpersonal mindfulness in marriage." However, it is seen that there are studies on interpersonal mindfulness in marriage descriptively (Pratscher et al., 2019; Erus, 2019; Deniz, Erus \&Batum, 2020; Batum, 2020; Sipahi, 2020). In these studies, it was concluded that married individuals with high levels of interpersonal mindfulness in marriage have high marital adjustment and life satisfaction in marriage.

In the relevant literature, there are relationship development programs based on the basic view of the concept of mindfulness and increase marital adjustment (Carson et al., 2004; Gambrel \& Piercy, 2015a). Carson et al. (2004), mindfulness-based stress reduction- relationship development program" was applied to spouses, and it was revealed that their marital well-being increased and their ability to cope with stress increased. Gambrel and Piercy (2015b) also developed a program of transition to mindful parenting for the couples expecting their first baby. This program includes the subjects of seeing the perspective of the spouse while interacting, being in the moment during communication, being able to control and express emotions, and conflict resolution. However, the results of the research revealed that there was not enough change in the behavior of their spouses. Also, communication problems were not fully resolved. Based on this result, it was concluded that it did not contribute much to communication and interaction (Gillespie et al., 2015). The MBSR program mostly includes meditation practices. In the individual, especially mindfulness as inner experiences. It is a program that provides development and supports individual development (Kabat-Zinn, 2005). Therefore, in this study, the concept of interpersonal mindfulness in marriage was studied. It is aimed for couples to gain effective communication skills and 
for couples to learn and develop positive behaviors. Interpersonal mindfulness in marriage provides that couples listen carefully to each other. The individual realizes and accepts the feelings- thoughts without judgment. The couples regulate behaviors and don't act impulsively (Erus,2019). According to the results of this research, positive behavioral changes were found in the couples who participated in the study following the program gains.

\section{Limitations and Recommendations}

As a result of all these findings and discussions, it has been determined that this program, which is made for married couples, is effective. In the research, the following suggestions can be made in line with all the applications and the results achieved:

In future studies, the number of sessions can be increased and the application can be spread over a longer period of time. After the completion of the program, mini-programs or supporting sessions can be applied in certain periods. Thus, the program can become more effective and skill acquisition can become continuous. In this study, 8 couples participated in sessions in the form of group counseling. In the following studies, the same program can be made with a single couple in the format of individual psychological counseling and the results can be compared. This study is limited to 8 couples living in Istanbul. Comparisons can be achieved by conducting simultaneous studies in other provinces of the country. Finally, after a certain period of time, studies can be carried out by bringing the same group together again. Comparison can be made with the test results currently performed. 


\section{REFERENCES}

Atkinson, B. J. (2013). Mindfulness training and the cultivation of secure, satisfying couple relationships. Couple and Family Psychology: Research and Practice, 22), 73-94. https://doi.org/10.1037/cfp0000002

Baer, R. A. (2003). Mindfulness training as a clinical intervention: A conceptual and empirical review. Clinical Psychology: Science and Practice, 10(2), 125-143. https://doi.org/10.1093/clipsy.bpg015

Barnes, S., Brown, K. W., Krusemark, E., Campbell, W. K., \& Rogge, R. D. (2007). The role of mindfulness in romantic relationship satisfaction and responses to relationship stress. Joumal of Marital \& Family Therapy, 33(4), 482-500. DOI: $10.1111 / \mathrm{j} .1752-0606.2007 .00033 . \mathrm{x}$

Batum, D. (2020). Examination of Personality Traits and Self-Understanding as Predictors of Interpersonal Conscious Mindfulness in Marriage [Master Thesis]. Yıldız Technical University.

Bishop, S. R., Lau, M., Shapiro, S., Carlson, L., Anderson, N. D., Carmody, J., ..., \& Devins, G. (2004). Mindfulness: A proposed operational definition. Clinical Psychology: Science and Practice, 11(3), 230-241. https://doi.org/10.1093/clipsy.bph077

Blanchflower, D. G.,\& Oswald, A. J. (2008). Is well-being U-shaped over the life cycle? Social Science \& Medicine, 69, 486-488. DOI: 10.1016/j.socscimed.2008.01.030.

Brown, K. W., \& Ryan, R. M. (2003). The benefits of being present: Mindfulness and its role in psychological wellbeing. Journal of Personality and Social Psychology, 84(4), 822-848. https://doi.org/10.1037/0022-3514.84.4.822

Bögels, S. M., Lehtonen, A., \& Restifo, K. (2010). Mindful parenting in mental health care. Mindfulness, 1(2), 107120. https://doi.org/10.1007/s12671-010-0014-5

Burgoon, J. K., Berger, C. R., \& Waldron, V. R. (2000). Mindfulness and interpersonal communication. Journal of Social Issues, 56(1), 105-127. https://doi.org/10.1111/0022-4537.00154

Burpee, L. C., \& Langer, E. J. (2005). Mindfulness and marital satisfaction. Journal of Adult Development, 12, 43-51. https://doi.org/10.1007/s10804-005-1281-6

Büyüköztürk, Ş., Çakmak, E. K., Akgün, Ö. E., Karadeniz, Ş., \& Demirel, F. (2017). Scientific research methods. Pegem Citation Index, 1-360.

Büyüköztürk, Ş., Çokluk, Ö., \& Köklü, N. (2013). Statistics for social sciences. Ankara: Pegem Publishing.

Carson, J. W., Carson, K. M., Gil, K. M., \& Baucom, D. H. (2004). Mindfulness-based relationship enhancement. Behaviour Therapy, 35, 471-494. https://doi.org/10.1016/S0005-7894(04)80028-5

Coatsworth, J., Duncan, L., Greenberg, M., \& Nix, R. (2010). Changing parent's mindfulness, child management skills and relationship quality with their youth: Results from a randomized pilot intervention trial. Journal of Child and Family Studies, 19(2), 203-217.

Carson, J. W., Carson, K. M., Gil, K. M., \& Baucom, D. H. (2004). Mindfulness-based relationship enhancement. Behaviour Therapy, 35, 471-494. https://doi.org/10.1016/S0005-7894(04)80028-5

Cohen, J. S., \& Miller, L. J. (2009). Interpersonal mindfulness training for well-being: A pilot study with psychology graduate students. Teachers College Record, 111(12), 2760-2774.

Deniz, M. E., Batum, D., Erus, S. M. (2019). Investigation of married individuals' conscious interpersonal mindfulness and emotion regulation difficulties in marriage [Conference presentation]. IX. International Higher Education Psychological Counseling and Guidance Research Congress. Marmara University, Istanbul.

Deniz, M. E., Erus, S. M. ve Batum, D. (2020). Examining marital satisfaction in terms of interpersonal mindfulness and perceived problem-solving skills in marriage. International Online Journal of Educational Sciences, 12(1), 1-15. http://dx.doi.org/10.15345/iojes.2020.02.005

Deniz, B. (2017). Investigation of Conscious Mindfulness Levels and Marital Satisfaction According to Personality Traits of Married Individuals. [Master Thesis. Üsküdar University]. 
Duncan, L. G. (2007). Assessment of mindful parenting among parents of early adolescents: Development and validation of the Interpersonal Mindfulness in Parenting Scales [Unpublished doctoral dissertation]. The Pennsylvania State University.

Duncan, L. G., Coatsworth, J. D., \& Greenberg, M. T. (2009). A model of mindful parenting: Implications for parent-child relationships and prevention research. Clinical child and family psychology review, 12(3), 255-270. https://doi.org/10.1007/s10567-009-0046-3

Elreda, Lauren, Molloy, Jennings, A. Patricia, DeMauro, A. Anthony, Mischenko, P. Polina, Brown, L. Joshua. (2019). Protective Effects of Interpersonal Mindfulness For Teachers' Emotional Supportiveness in The Classroom. Mindfulness, 10 (3): 537-546.

Erus, S., M. (2019). The Mediating Role of Emotional Intelligence and Marital Harmony in the Relationship Between Conscious Mindfulness and Subjective Well-being in Marriage. [Unpublished doctoral dissertation]. Yildız Technical University.

Erus, S., M., Deniz, M., E. (2018). Development of Conscious Mindfulness Scale in Marriage: Validity and Reliability Study. The Journal of Happiness Well-Being. c.6 p. 2: 96-113. https://doi.org/10.37217/tebd.796789

Frank, J. L., Jennings, P. A., \& Greenberg, M. T. (2016). Validation of the Mindfulness in Teaching Scale. Mindfulness, 7(1), 155-163. https://doi.org/10.1007/s12671-015-0461-0

Jones, C. Kendra, Welton, R. Sarah, Oliver, C. Tanner, Thoburn, W. John. 2011. Mindfulness, Spousal Attachment, and Marital Satisfaction: A Mediated Model. The Family Journal: Counseling and Therapy For Couples and Families.19 (4): 357-361. https://doi.org/10.1177/1066480711417234

Gambrel, L. E., \& Keeling, M. L. (2010). Relational aspects of mindfulness: Implications for the practice of marriage and family therapy. Contemporary Family Therapy, 32(4), 412-426. https://doi.org/10.1007/s10591010-9129.

Gambrel, L. E., \& Piercy, F. P. (2015a). Mindfulness-based relationship education for couples expecting their first child-Part 1: Randomized mixed-methods program evaluation. Journal of Marital and Family Therapy, 41(1), 524. https://doi.org/10.1111/jmft.12066

Gambrel, L. E., \& Piercy, F. P. (2015b). Mindfulness-based relationship education for couples expecting their first child-Part 2: Phenomenological findings. Journal of Marital and Family Therapy, 41 (1), 2541. https://doi.org/10.1111/jmft.12065

Germer, C. K. (2005). Mindfulness: What is it? What does it matter? In C. K. Germer, R. D. Siegel \& P. R. Fulton (Eds.), Mindfulness and psychotherapy, 3(27). New York: The Guilford Press.

Gillespie, B., Davey, M. P., \& Flemke, K. (2015). Intimate partners' perspectives on the relational effects of mindfulness-based stress reduction training: A qualitative research study. Contemporary Family Therapy, 37(4), 396-407. http://dx.doi.org/10.1007\%2Fs10591-015-9350-x

Gouveia, M. J., Carona, C., Canavarro, M. C., \& Moreira, H. (2016). Selfcompassion and dispositional mindfulness are associated with parenting styles and parenting stress: The mediating role of mindful parenting. Mindfulness, 7(3), 700-712. https://doi.org/10.1007/s12671-016-0507-y

Lenger, K. A., Gordon, C. L., \& Nguyen, S. P. (2017). Intra-individual and crosspartner associations between the five facets of mindfulness and relationship satisfaction. Mindfulness, 4(8), 171-180. https://doi.org/10.1007/s12671-016-0590-0

McCaffrey, S. (2015). Mindfulness in Parenting Questionnaire (MIPQ): Development and validation of a measure of mindful parenting (Unpublished doctoral dissertation). Nova Southeastern University, Florida

M. A., Duncan, L. G., Coatsworth, J. D., Nix, R. L., \& Greenberg, M. T. (2015). Understanding how mindful parenting may be linked to motheradolescent communication. Journal of youth and adolescence, 44(9), 16631673. https://doi.org/10.1007/s10964-015-0325-x 
Kabat-Zinn, J. (2003). Mindfulness-based interventions in context: Past, present, and future. Clinical psychology: Science and practice, 10(2), 144-156.

Kabat-Zinn, J. (2005). Full catastrophe of living. New York: Bantam Dell.

Khaddouma, A., Gordon, K. C., \& Bolden, J. (2015). Zen and the art of sex: Examining associationsamong mindfulness, sexual satisfaction, and relationship satisfaction in dating relationships. Sexual and Relationship Therapy, 30(2), 268-285. https://doi.org/10.1080/14681994.2014.992408

McCaffrey, S., Reitman, D., \& Black, R. (2017). Mindfulness in Parenting Questionnaire (MIPQ): Development and validation of a measure of mindful parenting. Mindfulness, 8(1), 232-246.

Özuğurlu, K. (2013). Marriage Report (Marriage-Family and Life Partnership). Istanbul: Golden Books Publishing House.

Parent, J., McKee, L. G., Rough, J. N., \& Forehand, R. (2016). The association of parent mindfulness with parenting and youth psychopathology across three developmental stages. Journal of Abnormal Child Psychology, 44(1), 191-202. doi: 10.1007/s10802-015-9978-x.

Parlar, A. and Akgün, SS. (2018). Investigation of the relationships between conscious mindfulness in marriage, marital satisfaction, and problem-solving skills. Academic Platform Journal of Education and Change, 1 (1), 11-21. https://doi.org/10.14527/pegegog.2020.011

Pratscher, S. D., Rose, A. J., Markovitz, L., \& Bettencourt, A. (2018). Interpersonal mindfulness: Investigating mindfulness in interpersonal interactions, corumination, and friendship quality. Mindfulness, 9(4), 12061215. https://doi.org/10.1007/s12671-017-0859-y

Pratscher, S. D., Wood, P. K., King, L. A., \& Bettencourt, B. A. (2019). Interpersonal mindfulness: Scale development and initial construct validation. Mindfulness, 10(6), 10441061. https://doi.org/10.1007/s12671-018-1057-2

Seller. B. (2018). Investigation of mediating roles of emotional intelligence and conscious mindfulness between perfectionism and romantic relationship satisfaction in young adults [Unpublished doctoral dissertation]. Yuldız Technical University.

Sipahi, T. (2020). Investigation of the Relationship Between Interpersonal Conscious Mindfulness and Relational Authenticity and Marital Life Satisfaction. [Unpublished Master Thesis]. Y1ldız Technical University.

Wachs, K., \& Cordova, J. V. (2007). Mindful relating: Exploring mindfulness and emotion repertoires in intimate relationships. Journal of Marital \& Family Therapy, 33(4), 464-481. https://doi.org/10.1111/i.17520606.2007.00032.x

Williams, A. M.,\& Cano, A. (2014). Spousal mindfulness and social support in couples with chronic pain. The Clinical Journal of Pain, 30(6), 528-535. https://doi.org/10.1097/ajp.0000000000000009 


\section{About Authors}

Gülgün Uzun. She completed her undergraduate education in the field of Guidance and Psychological Counseling at Çukurova University in 2012. Afterwards, she completed her master's degree in 2012 at Çukurova university and; completed doctorate at Yıldız Technical University in 2021. She is currently working as Psychological Counseler in the school in İstanbul.

Mehmet Engin Deniz. He completed his undergraduate education at Selcuk University, Psychological Counseling and Guidance Department in 1994. He received his Master's degree at 1997 and his doctorate degree at 2002 in the field of Psychological Services in Education at Selcuk University. He is still working as a professor at Yildı Technical University, Faculty of Education, Psychological Counseling and Guidance Department.

\section{Author Contributions}

This study was conducted by all the authors working together and cooperatively. All of the authors substantially contributed to this work in each step of the study.

\section{Conflict of Interest}

It has been reported by the authors that there is no conflict of interest.

\section{Ethical Statement}

This study was completed in accordance with the Helsinki Declaration. In line with this, the study was permitted by Research and Publication Ethics Committee of Yıldız Technical University.

Ethics Committee Name: Research and Publication Ethics Committee of Yildız Technical University. Approval Date: 27.05.2021

Approval Document Number: 104129 